\title{
Statyba
}

\section{MODIFIED SAWDUST CONCRETE}

\section{A. Kantautas \& G. Vaickelionis}

To cite this article: A. Kantautas \& G. Vaickelionis (2000) MODIFIED SAWDUST CONCRETE, Statyba, 6:2, 113-119, DOI: 10.1080/13921525.2000.10531574

To link to this article: https://doi.org/10.1080/13921525.2000.10531574

册 Published online: 26 Jul 2012.

Submit your article to this journal

ЏIII Article views: 412 


\section{MODIFIKUOTAS PJUVENŲ BETONAS}

\section{A. Kantautas, G. Vaickelionis \\ Kauno technologijos universitetas}

\section{Ivadas}

Pigios vietinès augalinès atliekos nuo seno buvo naudojamos Lietuvos kaimo statybose. Pjuvenu ir kitu organiniu atliekų betonas bei medbetonis ir dabar naudojamas namų sienų statybai, o pjuvenų ir kalkių mišinys sienu ir lubų šilumos izoliacijai. Statybiniai gaminiai iš medienos dalelių su mineralinèmis rišamosiomis medžiagomis sèkmingai naudojami daugelyje išsivysčiusių pasaulio šalių. Tax̌iau dažniausiai gaminamas specialiai paruoštas medienos užpildas, tuo tarpu pjuvenos praktiškai lieka nepanaudotos.

Šarminè cemento tešlos terpè skatina ekstraktụ išsiskyrimą iš medienos užpildo [1].

Medbetonio mišinius užmaišius vandeniu išsiskiria medienoje esantys sacharidai, kurie dèl adsorbcijos ir molekuliu sankabos jègu poveikio cemento grūdelių paviršiuje sudaro ploną adsorbcinị sluoksni. Cemento dalelès, padengtos tokia plèvele, negali agreguotis. Plèvelè trukdo vandeniui patekti prie cemento grūdeliu̧, kartu ir hidratacijos produktų migracijai nuo jų. Tai lètina cemento hidrolizę ir hidrataciją [2].

Betono su organiniais užpildais kokybę galima pagerinti pridejus $\mathfrak{i}$ mišini mineraliniu priedų. Šių priedų itaka nepakankamai ištirta ir jie mažai naudojami.

Darbe nagrinejama mineralinių priedu panaudojimo galimybé pjuvenu betono gamybai.

\section{Tyrimų metodika ir naudotos medžiagos}

Tyrimams naudota: portlandcementis CEM I 42,5R ir CEM I 32,5, trepelis, opoka, $950^{\circ} \mathrm{C}$ temperatūroje iš-

1 lentelè. Pjuvenų charakteristikos

Table 1. Characteristics of sawdust

\begin{tabular}{|l|c|c|c|c|c|c|}
\hline \multirow{2}{*}{ Pjuvenos ir jų sudètis, \% } & \multicolumn{5}{|c|}{ Dalinis likutis (\%) ant sietน kurių akelès mm } & Piltinis \\
\cline { 2 - 7 } & 2,5 & 1,6 & 1,0 & 0,63 & 0,4 ir likutis & tankis, $\mathrm{kg} / \mathrm{m}^{3}$ \\
\hline $\begin{array}{l}23,0 \% \text { lapuočiu ir } 77,0 \% \\
\text { spygliuočių }\end{array}$ & 3,32 & 17,69 & 26,98 & 31,18 & 20,83 & 89,5 \\
\hline
\end{tabular}

kaitintas molis, dolomitas, klintis, skalūno pelenai, smèlis, kalkès ir juairių medienos atmainų šviežios pjuvenos (1 lentelè).

Visi priedai, išskyrus smèlị, sumalti rutuliniame malūne ir pridèti užmaišant pjuvenų betono mišinị.

Priedų aktyvumas, t. y. savybè aplinkos temperatūroje sujungti kalcio hidroksidą pateiktas 2 lenteleje. Tai rodo, kiek miligramų $\mathrm{CaO}$ iš sočiojo kalkių tirpalo per 30 parų adsorbuoja $1 \mathrm{~g}$ priedo [3].

Tyrimams daugiausia imti $150 \times 150 \times 150 \mathrm{~mm}$ ir $40 \times 40 \times 160 \mathrm{~mm}$ matmenų bandiniai.

Gaminiu fizikinès ir mechaninès savybès nustatytos standartiniais metodais.

Stiprumas lenkiant nustatytas naudojant bandymų mašiną МИИ-100, o stipris gniuždant - hidraulinius presus $\Pi-10$ ir П-50.

Susitraukimo ir brinkimo deformacijos buvo nustatytos naudojant $40 \times 40 \times 160 \mathrm{~mm}$ prizmes ir laikrodinio tipo indikatorius (tikslumas $0,01 \mathrm{~mm}$ ).

Kadangi pjuvenu betonas pirmosiomis kietejimo paromis yra nestiprus, todèl bandiniai buvo specialiai paruošti, kad nejsmigtu indikatoriaus atramos. Ant viršutinès prizmès plokštumos vandeniui atspariais klijais buvo priklijuota metalinè plokštelè, $\mathfrak{i}$ kurią rèmèsi indikatoriaus atrama.

Nustačius susitraukimo ir brinkimo deformacijas, tie patys bandiniai buvo panaudoti dinaminio tamprumo moduliui nustatyti. Darbe naudotas mechaninių virpesių dažnio ir slopinimo matuoklis IČZ-9. 
2 lentelè. Mineralinių priedų hidraulinis aktyvumas

Table 2. Hydraulic activity of mineral additives

\begin{tabular}{|l|c|}
\hline Mineralinis priedas & Hidraulinis aktyvumas, $\mathrm{mg} \mathrm{CaO} / \mathrm{g}$ \\
\hline Trepelis & 360 \\
\hline Opoka & 310 \\
\hline Iškaitintas molis & 125 \\
\hline Dolomitas & 110 \\
\hline Klintis & 100 \\
\hline Smèlis & - \\
\hline Kalkès & - \\
\hline Skalūno pelenai & - \\
\hline
\end{tabular}

Šilumos laidumo koeficientas nustatytas „Dr. Bock Bauart Weiss" sistemos šilumos laidumo matavimo prietaisu (GOST 7076-78), naudojant 250x250x50 mm matmenų bandinius.

\section{Rezultatai ir jų aptarimas}

Mineraliniu priedų efektyvumo tyrimų rezultatai pateikti 3 lentelèje. Iš jų matyti, kad kuo didesnis priedo aktyvumas, tuo šis priedas efektyvesnis. Geriausiai tai patvirtina šutintų bandinių tyrimo rezultatai. Apie priedo efektyvumą galima spręsti iš sutintų ir natūraliomis sąlygomis kietejusiu bandiniu stipriu gniuždant santykio, išreikšto \%. Kuo šis santykis artimesnis $100 \%$, tuo priedas efektyvesnis. Gautieji rezultatai patvirtina, kad priedo efek- tyvumas proporcingas hidrauliniam jo aktyvumui. Placiai naudojamas priedas - smèlis nèra efektyvus, bet jis mažina pjuvenu betono deformacines savybes, todel yra pageidautinas. Bandiniai su kalkių ir skalūno pelenų priedu po sutinimo buvo išsipūtę ir suiro, imant juos iš formų.

Iš rezultatų (3 lentelè) matyti ir tai, kad kalkių ir skalūno pelenu priedas turi teigiamos itakos pjuvenų betonui, kietejančiam natūraliomis salygomis. Kalkès ir skalūno pelenai yra ne tik mineralizatoriai, bet ir savarankiškos rišamosios medžiagos. Bandymu rezultatai patvirtina, kad pjuvenu betono gamybai neracionalu naudoti daug aukštos markès portlandcemencio, kadangi naudojant tokị pati mažiau aktyvios mineralinès rišamosios medžiagos (kalkès ir kuro pelenai) arba pucolaninès medžiagos priedą gaunami tokie pat ar net geresni rezultatai.

Nustatyta, kad naudojant toki patị portlandcemenčio ir opokos rišamosios medžiagos priedo kiekị, i tirpalą išsiskiria mažiau tirpių medžiagų, nei naudojant portlandcemenčio priedą, be to, mažesnis gauto tirpalo $\mathrm{pH}$ (4 lentelè). Šj ekstrakto koncentracijos sumažejimą galima paaiškinti dvejopai: pirma, hidrauliniai mineraliniai priedai (opoka) savo paviršiumi absorbuoja tirpias medienos medžiagas ir sumažina jų koncentraciją tirpale, antra, $i$ cementini mišinị pridètas hidraulinis priedas sumažina tešlos pH ir medienos užpilde esanti hemiceliuliozè mažiau skyla ị monosacharidus.

3 lentelè. Mineralinių priedu itaka pjuvenų betono (cementas -1 masès dalių, pjuvenos $-0,45$ masès dalių, priedas $-0,3$ masès daliu, vanduo - 0,83-0,92 masès daliu) stipriui

Table 3. Influence of mineral additives on sawdust concrete (cement -1 mass part, sawdust $-0,45$ mass part, additives $-0,3$ mass part, water $-0,83-0,92$ mass part) strength

\begin{tabular}{|c|c|c|c|c|c|c|c|c|c|}
\hline \multirow{3}{*}{ Priedas } & \multicolumn{6}{|c|}{ Bandinių stipris gniuždant, $\mathrm{MPa}$} & \multirow{2}{*}{\multicolumn{3}{|c|}{$\left(\mathbf{R}_{\text {gn . sut }} / \mathbf{R}_{\text {gn n.k. }}\right) \times 100 \%$}} \\
\hline & \multicolumn{3}{|c|}{ Natūraliai kietėjusių } & \multicolumn{3}{|c|}{ Šutintų ir natūraliai kietejjusių } & & & \\
\hline & 3 paras & 7 paras & 56 paras & 1 parą & 7 paras & 56 paras & 3 paras & 7 paras & 56 paras \\
\hline Be priedo & 2,73 & 3,39 & 4,36 & 1,61 & 1,80 & 1,99 & 59,19 & 53,10 & 45,64 \\
\hline Cementas* & 4,12 & 5,19 & 7,09 & 2,39 & 3,23 & 4,98 & 58,01 & 62,24 & 70,27 \\
\hline Trepelis & 3,79 & 5,14 & 7,52 & 3,71 & 4,72 & 7,35 & 98,00 & 91,82 & 97,74 \\
\hline Opoka & 3,51 & 4,91 & 8,25 & 3,41 & 4,46 & 7,76 & 97,10 & 90,92 & 94,06 \\
\hline Iškaitintas molis & 3,40 & 4,83 & 7,01 & 2,59 & 3,38 & 5,12 & 76,15 & 69,97 & 73,03 \\
\hline Dolomitas & 3,11 & 4,33 & 5,87 & 1,86 & 2,37 & 4,24 & 59,94 & 54,76 & 72,18 \\
\hline Klintis & 3,09 & 4,26 & 5,61 & 1,92 & 2,39 & 3,99 & 62,28 & 56,10 & 71,12 \\
\hline Smèlis & 2,73 & 3,40 & 4,57 & 1,74 & 1,91 & 2,40 & 63,74 & 56,18 & 52,51 \\
\hline Kalkès & 4,15 & 5,22 & 7,14 & - & - & - & - & - & - \\
\hline Malti skalūno pelenai & 3,43 & 5,41 & 7,43 & - & - & - & - & - & - \\
\hline Nemalti skalūno pelenai & 3,08 & 5,15 & 7,05 & - & - & - & - & - & - \\
\hline
\end{tabular}

* Cemento kiekis yra $1,0+0,3=1,3$ masès dalys 
Kai rišamosios medžiagos panaudota daugiau kaip $10 \mathrm{~g}$, ekstrakto koncentracijos mažèjimą abiem atvejais galima sieti su tuo, kad medienos dalelès padengiamos vis storesniu rišamosios medžiagos sluoksneliu ir ekstraktyvai jau nebegali pereiti i tirpalą. Panaudojus $30 \mathrm{~g}$ cemento ir opokos mišinio, visas vanduo buvo sujungtas ir ekstrakto nepavyko išskirti.

4 lentelè. Portlandcemenčio CEM I 32,5 (savitasis paviršius $300 \mathrm{~m}^{2} / \mathrm{kg}$ ) ir portlandcemenčio bei opokos rišamosios medžiagos $\left(50 \%+50 \%\right.$ savitasis paviršius $\left.750 \mathrm{~m}^{2} / \mathrm{kg}\right)$ priedu itaka drebulès ekstrakto ( $10 \mathrm{~g}$ pjuvenu užpilta $100 \mathrm{ml}$ vandens) rodikliams, kai ekstrakcija vyko $80^{\circ} \mathrm{C}$ temperatūroje 24 valandas

Table 4. Influence of cement and cement-gaize binding material additives on asp extract data

\begin{tabular}{|c|c|c|c|c|}
\hline $\begin{array}{c}\text { Priedo } \\
\text { kiekis, } \\
\mathrm{g}\end{array}$ & \multicolumn{2}{|c|}{ Portlandcementis } & \multicolumn{2}{c|}{$\begin{array}{c}\text { Portlandcementis + } \\
\text { opoka }\end{array}$} \\
\cline { 2 - 5 } & $\begin{array}{c}\text { Ekstrakto } \\
\mathrm{pH}\end{array}$ & $\begin{array}{c}\text { Ekstrakto kon- } \\
\text { centracija, \% }\end{array}$ & $\begin{array}{c}\text { Ekstrakto } \\
\mathrm{pH}\end{array}$ & $\begin{array}{c}\text { Ekstrakto } \\
\text { koncentracija,\% }\end{array}$ \\
\hline- & 7,55 & 0,149 & 7,40 & 0,153 \\
\hline 2,5 & 10,35 & 0,728 & 9,50 & 0,604 \\
\hline 5,0 & 10,50 & 0,878 & 10,12 & 0,743 \\
\hline 7,5 & 11,60 & 0,923 & 11,32 & 0,749 \\
\hline 10 & 11,85 & 0,902 & 10,92 & 0,702 \\
\hline 20 & 12,08 & 0,552 & 11,32 & 0,460 \\
\hline 30 & 12,15 & 0,449 & - & - \\
\hline
\end{tabular}

Ištirtos betonฯ mišinių sudètys plačiu portlandcemenčio ir trepelio kompozicinès rišamosios medžiagos ir pjuvenu santykių intervalu.

1 paveiksle parodyta cemento ir trepelio masių santykio bei pjuvenų ir rišamosios medžiagos tūrio santykio priklausomybè betonui kietejjant hidroterminèmis sąlygomis.

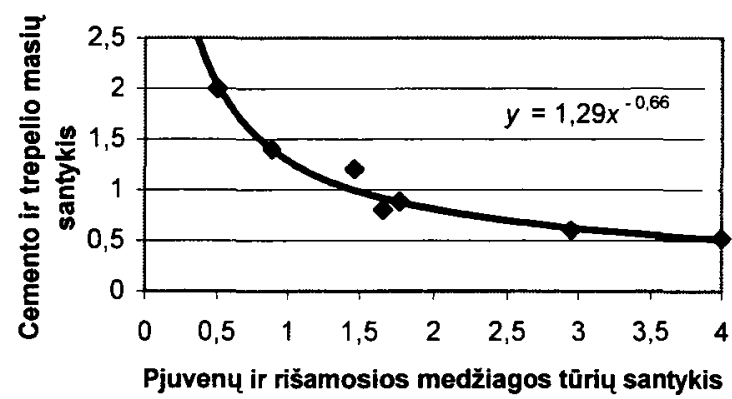

1 pav. Cemento ir trepelio masiu santykio bei pjuveny ir rišamosios medžiagos tūrių santykio priklausomybe

Fig 1. Dependency of cement and rottenstone mass upon sawdust and binding material volume
Nustatyta, kad optimaliai šị saryši aprašo lygtis:

$$
y=1,29 \cdot x^{-0,66},
$$

čia $y$ - cemento ir trepelio masiu santykis, $x$ - pjuvenų ir rišamosios medžiagos tūrių santykis.

Pagal šią lygti galima nustatyti optimalų cemento ir trepelio santyki, kai betono mišinyje keičiamas pjuvenu kiekis.

Formavimo mišinyje didinant pjuvenu kieki rišamojoje medžiagoje reikia didinti ir hidrauliškai aktyvios medžiagos kiekị.

Pjuvenų betonui kietėjant žemesnèse temperatūrose tirpių ekstraktyvių medžiagų iš medienos užpildo išsiskiria mažiau ir todèl reikia mažiau trepelio.

Ištirta pjuvenų betono bandinių išlaikymo prieš šutinimą trukmès itaka betono stiprumui. Prieš šutinimą bandinius su portlandcemencio-trepelio rišamaja medžiaga reikia išlaikyti 4-6 valandas. Tuo tarpu bandinių be trepelio priedo negalima šutinti, nes jie išsipučia ir praranda stipruma.

Trepeli pakeitus opoka, esminių pokyčiu nepastebèta. Pirmosiomis kietejimo paromis geresni stiprumo rodikliai gauti naudojant trepelio prieda, bet po 28 paru, 3 ir 6 mènesių kietejjimo šis skirtumas išnyksta. Tikriausiai tai susiję su didesniu trepelio, palyginti su opoka, hidrauliniu aktyvumu.

Remiantis literatūros analize ir ilgalaikiais pjuvenu ir pjuvenu betonu tyrimais, nustatyta, kad optimalus kalcio chlorido kiekis, naudojamas ruošiant betono mišinius su ivairiomis rišamosiomis medžiagomis, yra 12-15\% panaudotų pjuvenų masès. Kalcio chloridas veikia kaip kompleksinis priedas, greitinantis rišamosios medžiagos kietejima, ir kaip pjuvenų mineralizatorius. Tikslus kalcio chlorido kiekis priklauso nuo daugelio veiksnių: nuo pjuvenu smulkumo, daleliu formos, medienos rūšies, nuo rišamosios medžiagos. Imant smulkesnes ir su didesniu lapuočiu medienos kiekiu pjuvenas, kalcio chlorido reikia daugiau. Naudojant cemento ir opokos (trepelio) rišamaja medžiaga, galima ir visai apsieiti be kalcio chlorido priedo.

Nustatyta sukietejusių bandinių drégnio ittaka pjuvenц betono stipriui. Yra žinoma, kad kietèjant arbolitui, jo stipris dideja neproporcingai sumažejusio drègnio kiekiui. Didžiausias arbolito stipris yra, kai jo drègnis 15-17\%. Toliau mažejant drègniui, destrukcinių procesų atsirandančiu dèl padidejusio bandiniu susitraukimo, stipris taip pat mažèja [4]. 
Kreivè neturi ekstremumo ( 2 pav.), kaip ir arbolito atveju [5]. Iš 2 pav. matyti, kad pjuvenu betono stiprumas, mažèjant gaminio drègniui, dideja. Nustatyta, kad optimaliai šị ryši aprašo lygtis:

$$
y=-0,96 \cdot \ln (X)+7,9
$$

Pagal šią lygti apskaičiuota, kad:

$$
y=0,96 \cdot \ln \left(\frac{W}{X}\right)+R
$$

čia $R$ - žinomas gaminio stipris gniuždant (MPa), kai jo drègnis $W(\%), y$ - prognozuojamas gaminio stipris gniuždant (MPa), kai jo drégnis $X(\%)$.

Pagal šią lygti galime nustatyti gaminio stiprumą gniuždant, esant ịvairiam jo drègniui.

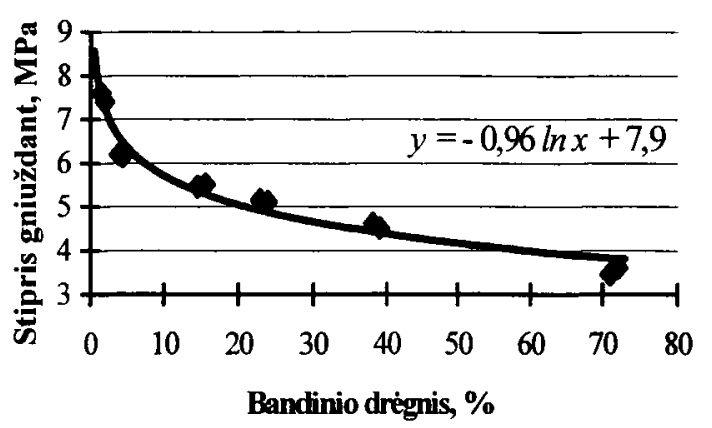

2 pav. Pjuvenų betono bandiniu drègnio itaka stipriui gniuždant

Fig 2. Influence of sawdust concrete humidity on its compressive strength

Ištirta cikliško džiovinimo ir drèkinimo itaka cemento-trepelio (opokos)-pjuvenų betono savybèms. Atlikus 20 džiovinimo ir drèkinimo ciklų nebuvo pastebèta esminio bandiniu stiprumo sumažèjimo, taip pat nepasi- keite ir pjuvenų betono išvaizda (neatsirado ịtrükimų ar nutrupejjimu).

Malta klintis taip pat yra nedidelio hidraulinio aktyvumo ir klintmilčiu priedas betone duoda teigiamus rezultatus.

Optimalus pridedamų maltų klinčiu priedo kiekis sudaro $50-75 \%$ nuo cemento kiekio. Labiausiai klinčiu priedo itaka pasireiškia pradinèse betono kietejjimo proceso stadijose ir kai betono sudètyse yra mažas cemento kiekis. Šiuo atveju bandiniu stipris, palyginti su kontroliniais (be klinčiu priedo), padidejja 1,5-3,5 karto.

Cemento sąnaudos pjuvenų betone, kurio tankis $750-1100 \mathrm{~kg} / \mathrm{m}^{3}$, turi sudaryti ne mažiau kaip $300 \mathrm{~kg} / \mathrm{m}^{3}$. Priklausomai nuo ivairiu technologinių faktorių tokio betono stipris gniuždant gali būti nuo 3 iki $17 \mathrm{MPa}(5$ lentelè).

Kadangi medienos ir cemento kompozicinèms medžiagoms būđingos didelès susitraukimo ir brinkimo deformacijos, šiems tyrimams skirtas ypatingas dèmesys. Buvo matuojamos susitraukimo deformacijos gaminiui kietejant ir džiūstant, jam brinkstant vandenyje ir pakartotinai džiūstant.

Pjuvenų betonas ruoštas su smèlio priedu ir be jo.

Absoliučios susitraukimo deformacijos po 1,5 mén. kietejimo gana didelès ir natūraliomis sąlygomis kietèjusio betono yra $8-13,7 \mathrm{~mm} / \mathrm{m}(0,8-1,37 \%)$, o sutinto $5,2-8,6 \mathrm{~mm} / \mathrm{m}(0,52-0,86 \%)$. Šios deformacijos beveik atitinka arbolito susitraukimo deformacijas [4].

Brinkimo deformacijos уга $1,1-2,5 \mathrm{~mm} / \mathrm{m} \quad(0,1-$ $0,25 \%$ ) ir taip pat neviršija arbolito brinkimo deformaciju $(0,2-0,25 \%)$ [4]. Tik bandiniuose be smèlio brinkimo deformacijos siekia $3,2-4,5 \mathrm{~mm} / \mathrm{m}(0,32-0,45 \%)$.

5 lentelè. Pjuvenų betono su skirtingais rišamosios medžiagos ir pjuvenų tūrių santykiais savybès. Portlandcemenčio ir trepelio (opokos) santykis rišamojoje medžiagoje yra optimalus

Table 5. Properties of sawdust concrete with different binding material and sawdust volume relation. Cement and rottenstone (gaize)

\begin{tabular}{|c|c|c|c|c|c|}
\hline \multirow{2}{*}{$\begin{array}{l}\text { Rišamosios medžiagos ir } \\
\text { pjuvenų tūrio santykis }\end{array}$} & \multirow{2}{*}{$\begin{array}{c}\text { Rišamosios medžiagos } \\
\text { sq̨audos, } \mathrm{kg} / \mathrm{m}^{3}\end{array}$} & \multirow{2}{*}{$\begin{array}{c}\text { Pjuvenu betono } \\
\text { tankis, } \mathrm{kg} / \mathrm{m}^{3}\end{array}$} & \multicolumn{2}{|c|}{ Bandinių stipris gniuždant, $\mathrm{MPa}$} & \multirow{2}{*}{$\begin{array}{c}\text { Bandinio drègnis, } \\
\%\end{array}$} \\
\hline & & & šutintų & po 28 pary & \\
\hline $1: 2,95$ & 609 & 810 & 3,24 & 4,20 & 61 \\
\hline $1: 1,77$ & 694 & 865 & 5,83 & 7,61 & 55 \\
\hline $1: 1,66$ & 702 & 869 & 7,20 & 10,56 & 57 \\
\hline $1: 1,47$ & 760 & 862 & 7,75 & 10,72 & 59 \\
\hline $1: 0,88$ & 966 & 1064 & 13,74 & 17.60 & 43 \\
\hline
\end{tabular}
relation in the binding material is optimal 
Pakartotinai betonas traukiasi daug mažiau. Betonas su smèlio priedu susitraukia ne daugiau kaip $2 \mathrm{~mm} / \mathrm{m}$ $(0,2 \%)$, o be smèlio - šiek tiek daugiau - $2,7-4,1 \mathrm{~mm} / \mathrm{m}$ $(0,27-0,41 \%)$. Taigi išdžiovintų gaminiu susitraukimo deformacijos yra nedidelès.

Šutintu bandinių deformacijos mažesnès, negu bandinių, kietejjusių natūraliomis sąlygomis. Todèl pjuvenu betono gaminius prieš naudojimą ir apdailinimą reikia išdžiovinti.

Atlikus susitraukimo ir brinkimo deformaciju tyrimus su tais pačiais bandiniais nustatytas pjuvenц betono dinaminis tamprumo modulis. Matavimai atlikti su mechaninių virpesių dažnio ir slopinimo matuokliu IČZ-9.

Bandiniai tirti pagal [6] metodiką ir rezultatai apskaičiuoti pagal šią formulę:

$$
E_{\text {din. }}=0,965 \cdot 10^{-3} \cdot\left(\frac{l}{h}\right)^{3} \cdot \frac{P \cdot f_{l}^{2}}{b} \cdot T,
$$

čia $E_{\text {din }}$ - dinaminis tamprumo modulis, $\mathrm{kG} / \mathrm{cm}^{2} ; f_{l}$ - rezonansinis dažnis, $\mathrm{Hz} ; h$ - bandinio skerspjūvio aukštis virpesių kryptimi, cm; $b$ - bandinio skerspjūvio plotis, $\mathrm{cm} ; l$ - bandinio ilgis, $\mathrm{cm} ; T$ - koeficientas, 1,4 .

Dinaminis tamprumo modulis rodo tik tampriąsias medžiagos savybes, bet neivertina valkšnumo, nes virpanciame bandinyje atsiranda tik labai maži itempimai. Dèl šios priežasties dinaminis tamprumo modulis daug didesnis už statini tamprumo modulị. Dinaminio ir statinio tamprumo modulių reikšmiu skirtumą lemia tai, kad betono heterogeniškumas šiuos modulius veikia skirtingais mechanizmais. 3 pav. parodyta statinio ir dinaminio modulio santykio priklausomybe nuo betono stiprio [7].
Statinio tamprumo modulio reikšmès, apskaičiuotos pagal 3 pav., pateiktos 6 lentelèje.

Iš 6 lenteles duomenų matyti, kad pjuvenu betonu, ypač be smèlio priedo ( $1,5,6$ sudètys), tamprumo modulis savo reikšmemis artimas lengvujų betonų su poringais užpildais tamprumo moduliams, esant tam pačiam betono stiprumui ir 1,7-2,5 karto mažesnis už sunkiojo betono tamprumo modulius.

Imant daugiau rišamosios medžiagos ir smèlio ( 9 sudettis), šių betonu tamprumo modulis artimas atitinkamo stiprumo sunkiojo betono tamprumo moduliui. Smèlio priedas pjuvenu betono sudetyse turi teigiamos itakos betono deformacinems savybèms ir tamprumo modulis padideja. Taigi pjuvenų betono tamprumo savybes galime reguliuoti, keisdami jo struktūrą.

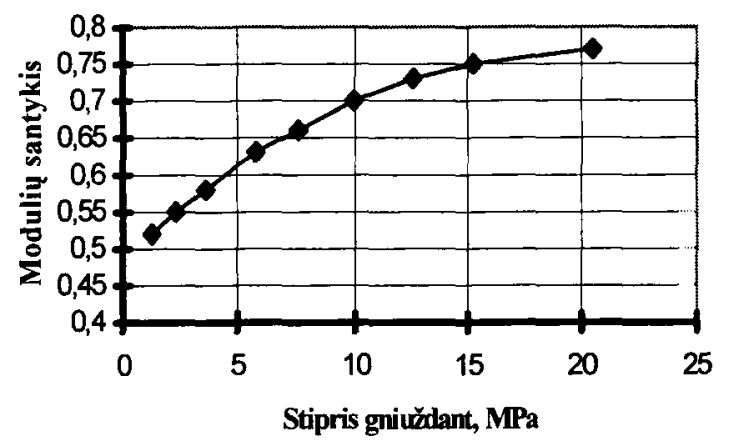

3 pav. Betono stiprio itaka statinio ir dinaminio tamprumo modulių santykiui

Fig 3. Influence of concrete compressive strength on the relation of static and dynamic elasticity moduli

6 lentelè. Ivairių pjuvenų betono suděčị tamprumo moduliai

Table 6. Elasticity moduli of various compositions of sawdust concrete

\begin{tabular}{|c|c|c|c|c|}
\hline $\begin{array}{c}\text { Sudèties šifro } \\
\text { Nr. }\end{array}$ & $\begin{array}{c}\text { Betono tankis, } \\
\mathrm{kg} / \mathrm{m}^{3}\end{array}$ & Stipris gniuždant, MPa & $\begin{array}{c}\text { Dinaminis tamprumo modu- } \\
\text { lis, MPa }\end{array}$ & $\begin{array}{c}\text { Statinis tamprumo mo- } \\
\text { dulis, MPa }\end{array}$ \\
\hline 1 & 776 & 6,37 & 7685 & 4918 \\
\hline 2 & 974 & 6,56 & 8785 & 5622 \\
\hline 3 & 968 & 11,29 & 11715 & 8318 \\
\hline 4 & 968 & 12,51 & 11563 & 8383 \\
\hline 5 & 927 & 15,39 & 14912 & 11184 \\
\hline 6 & 927 & 14,69 & 14966 & 11150 \\
\hline 7 & 1189 & 14,67 & 17659 & 13156 \\
\hline 8 & 1189 & 13,97 & 17059 & 12624 \\
\hline 9 & 1343 & 15,85 & 29759 & 22468 \\
\hline
\end{tabular}


7 lentelé. Pjuvenų betono ir arbolito šilumos laidumo koeficientai

Table 7. Coefficients of heat conductivity of sawdust concrete and arbolite

\begin{tabular}{|c|c|c|c|c|c|c|c|c|}
\hline & \multicolumn{8}{|c|}{ Šilumos laidumo koeficientai, $\mathrm{W} /(\mathrm{m} \cdot \mathrm{K})$, kai tankis, $\mathrm{kg} / \mathrm{m}^{3}$} \\
\hline & 500 & 600 & 700 & 800 & 900 & 1000 & 1100 & 1200 \\
\hline Arbolitas (sausas) & 0,095 & 0,12 & 0,14 & 0,16 & 0,18 & - & - & - \\
\hline Pjuvenų betonas (sausas) & 0,116 & 0,145 & 0,162 & 0,178 & 0,193 & 0,207 & 0,220 & 0,234 \\
\hline \multicolumn{9}{|c|}{$\begin{array}{l}\text { Apskaičiuotos reikšmès, kai gaminio } \\
\text { drėgnis: }\end{array}$} \\
\hline $\mathrm{W}=10 \%$ & 0,174 & 0,217 & 0,243 & 0,267 & 0,289 & 0,310 & 0,330 & 0,351 \\
\hline$W=15 \%$ & 0,199 & 0,246 & 0,271 & 0,293 & 0,313 & 0,331 & 0,346 & 0,362 \\
\hline
\end{tabular}

Nustatant pjuvenų betono atsparumą šalčiui, buvo tirti bandiniai, pagaminti iš liesujų ( $3: 1)$ ir riebiujų $(5: 1)$ mišinių be smèlio priedo.

Liesujų betonų (3:1) stipris gniuždant po 25 šaldymo ciklų sumažèjo $13,8 \%$, o masès nuostoliai siekè $2,8 \%$. Po 50 šaldymo ciklų stipris gniuždant sumažèjo $29,8 \%$, o masès nuostoliai siekè $9,07 \%$. Riebiuju betonų ( $5: 1)$ po 75 saldymo ciklų stipris gniuždant sumažèjo $9,8 \%$, o masès nuostoliai siekè $2 \%$. Pridejus prie šių sudéčiu smèlio prieda, atsparumas šalčiui padidèţ, nes, kaip buvo nustatyta, tada sumažèja susitraukimo deformacijos.

Galima daryti išvadą, kad paruoštu sudèčiu pjuvenų betono atsparumas šalčiui ne mažesnis kaip 25-75 ciklai.

Arbolito atsparumas šalčiui - ne mažesnis kaip 2550 ciklų [4].

Pjuvenų betonai pasižymi mažu šilumos laidumu, artimu arbolitui ( 7 lentelè). Tai leidžia šias medžiagas naudoti konstrukcinių termoizoliacinių medžiagu gamybai.

\section{Išvados}

1. Pjuvenu betono mišiniuose hidrauliniai priedai efektyviai sumažina pjuvenose esančių ekstraktų neigiamą itaką rišamuju medžiagu hidratacijai, todèl pjuvenų nereikia papildomai mineralizuoti.

2. Hidrauliniai (pucolaniniai) ir kiti panašūs priedai: malta opoka, trepelis, degtas molis, klintmilčiai, dolomitas bei skalūno pelenai - gali būti naudojami kaip efektyvi pjuvenų betono sudedamoji dalis bei mineralizuojantis priedas. Šie priedai yra geri betonui kietèjant natūraliomis salygomis ir ypač efektyvūs betona apdorojant hidrotermiškai (šutinant). Priedus pagal efektyvumo mažejimą galima išdèstyti ị tokią eilę: trepelis, opoka, degtas molis, dolomitas, klintis.
3. Nustatyta, kad pjuveny betono mineralinè sudedamoji dalis (priedai) daro teigiama itaka cemento rišimuisi ir kietèjimui dèl dviejų priežasčių: 1) hidrauliniai ir kiti naudoti mineraliniai priedai iš skystosios fazès absorbuoja ekstraktyvias, cemento kietèjimą lètinančias medžiagas ir taip sumažina jų koncentraciją tirpale ir 2) sumažina skystosios fazès $\mathrm{pH}$, todèl pjuvenose ar kitame augalinès kilmès užpilde esanti hemiceliuliozè mažiau skyla i paprastuosius cukrus.

4. Optimalu cemento ir trepelio santyki pjuvenu betono mišinyje galima apskaičiuoti pagal formulę:

$$
y=1,29 \cdot x^{-0,66}
$$

cia $y$-cemento ir trepelio masès santykis, $x$ - pjuvenu ir rišamosios medžiagos tūrio santykis (rišamoji medžiaga portlandcementis + trepelis).

5. Nustatyta matematiné priklausomybè tarp stiprio gniuždant ir bandinio drègnio:

$$
y=0,96 \cdot \ln \left(\frac{W}{X}\right)+R,
$$

čia $R$ - žinomas gaminio stipris gniuždant (MPa), kai jo drègnis $W(\%), y$ - prognozuojamas gaminio stipris gniuždant (MPa), kai jo drègnis $X(\%)$.

6. Naudojant portlandcemenčio ir mineralinio priedo mišini, galima gaminti natūralaus kietejjimo ir sutintą pjuvenų betona, kurio tankis $750-1200 \mathrm{~kg} / \mathrm{m}^{3}$ ir stipris gniuždant 3-17 MPa.

7. Pjuvenų betono atsparumas šalčiui ne mažesnis kaip 25-75 ciklai.

8. Išdžiovintų gaminių susitraukimo deformacijos yra nedidelès. Pjuvenų betonai pasižymi mažu šilumos laidumu, dèl to šios medžiagos tinka mažagabaričių konstrukcinių termoizoliacinių medžiagu gamybai. 


\section{Literatūra}

1. Н.И. Никитин. Химия древесины и целлюлозы Москва-Ленинград: Изд. АН СССР, 1962. 711 с.

2. Л. П. Хорошун, А. С. Щербаков. Прочность и деформативность арболита. Киев: Наукова думка, 1979. 191 с.

3. F. Aleinikovas, V. Jasiukevicius, V. Latvys ir kt. Bendrosios silikatu technologijos laboratoriniai darbai. Vilnius: Mintis, 1967.

4. И. Х. Наназашвили. Строительные материалы из древесноцементной композиции. Ленинград: Стройиздат, $1990.415 \mathrm{c}$

5. В. И. Бухаркин и др. Использование древесных отходов для производства арболита (опыт работы предприятий). Москва: Древесная промышленность, 1975.

6. Проекты нормативных документов на определение акустических характеристик материалов и на использование этих характеристик для определения качества бетона в образцах, изделиях и конструкциях. Рига, 1962.

7. А.М. Невиллю Свойства бетона (перевод с англ.). Москва: Издательство литературы по строительству, 1972.

Iteikta 19991108

\section{MODIFIED SAWDUST CONCRETE}

\section{A. Kantautas, G. Vaickelionis}

\section{Summary}

Wood-cement materials are widely produced and applied in many developed countries. In this case special prepared wood aggregates are employed. Wood sawdust practically is not employed.

Extracts, present in wood, slow down the cement hydration. The influence of mineral additives on this process was determined. The efficiency of mineral additives depends on their hydraulic activity.

It has been found that the mineral components (additives) of sawdust concrete have a positive effect on cement setting and hardening due to two reasons: 1) hydraulic and other mineral additives absorb wood extracts from liquid phase which inhibit and retard setting of cement and reduce their concentration in solution; 2) reduce $\mathrm{pH}$ of liquid phase so the hemicellulose which is in sawdust or other wood aggregates, less disintegrate lightly soluable sugars.

When sawdust amounts are different, the optimum cement and rottenstone relation is not constant:

$$
y=1,29 x^{-0,66},
$$

where $y$ is cement and rottenstone mass relation, $x$ is sawdust and binding material (cement+rottenstone) volume relation.
The influence of sawdust concrete humidity on its strength was found:

$$
y=0,96 \cdot \ln \left(\frac{W}{X}\right)+R,
$$

where $y$ is concrete compressive strength (MPa), when its humidity $X(\%), R$ is concrete compressive strength $(\mathrm{MPa})$, when its humidity $W(\%)$.

The possibility of accelerating the hardening process of concrete mixes of cement-rottenstone (gaize)-sawdust system by means of steaming at $80^{\circ} \mathrm{C}$ was studied, too. It is impossible when producing ordinary wood-cement materials.

The physical and technical properties of sawdust concrete such as shrinkage strain, expansion deformations and elastic modulus were determined.

Sawdust concrete contraction deformation depending on concrete density may vary by $8 \ldots 14 \mathrm{~mm} / \mathrm{m}$ and expansion (in humid conditions) by $1,1 \ldots 2,5 \mathrm{~mm} / \mathrm{m}$. Deformation decreases when quartz sand additive is used. When the concrete gets dry repeatedly, deformations are smaller.

The sawdust concrete elasticity modulus is similar to that of light concrete with inorganic additives having the same density.

Its frost resistance depends on the concrete structure and cement quantity. When the concrete with a small amount of sawdust is used (cement+additive:sawdust=5:1), the samples endure 75 freezing cycles.

The heat conductivity of sawdust concrete is low.

The experimental data have shown that structural thermoinsulated small blocks can be produced from these concrete mixes.

Aras KANTAUTAS. Doctor, Associate Professor. Dept of Silicate Technology. Kaunas University of Technology. Radvilènu pl. 19, LT-3028 Kaunas, Lithuania.

A graduate of Kaunas Politechnic Institute (presently Kaunas University of Technology) (1990). Doctor (technical sciences, 1996). Author and co-author of 22 scientific articles and 2 study-guides. Research interests: properties of silicate binding materials, chemistry engineering.

Giedrius VAICKELIONIS. Doctor, Associate Professor. Dep of Silicate Technology. Kaunas University of Technology. Radvilènų pl. 19, LT-3028 Kaunas, Lithuania.

A graduate of Kaunas Politechnic Institute (presently Kaunas University of Technology) (1981). Doctor (technical sciences, 1997). Author and co-author of 15 scientific articles, 2 inventions and 2 study-guides. Research interests: properties of sawdust concrete, properties and technology of glass. 